\title{
MUSIM PENANGKAPAN IKAN LEMURU, Sardinella lemuru, Bleeker 1853 DI PERAIRAN SELAT BALI
}

\author{
( Gede Sedana Merta") dan Subhat Nurhakim")
}

\begin{abstract}
ABSTRAK
Perikanan lemuru, Sardinella lemuru, Bleeker 1853 di Selat Bali dapat membentuk suatu biomassa yang tinggi karena terjadi proses upwelling pada musim timur, dimulai pada akhir bulan April dan berakhir pada permulaan bulan Oktober. Ikan lemuru mempunyai pola musim yang umum, yaitu musim pada bulan-bulan September sampai dengan Desember dan tidak musim pada bulan-bulan lainnya, meskipun ikan lemuru juga tertangkap sepanjang tahun. Musim tahunannya sering berubah karena adanya pengaruh dari terjadinya $\mathrm{EI}$ Nino. El Nino ini juga berpengaruh terhadap pendaratan ikan lemuru di Selat Bali, di mana pendaratan tinggi bila terjadi EI Nino dan rendah selama anti EI Nino.
\end{abstract}

\section{ABSTRACT: $\quad$ Catch season of lemuru, sardinella lemuru, Bleeker 1853 in Bali Strait waters. By: I Gede Sedana Merta and Subhat Nurhakim}

Lemuru, Sardinella lemuru, Bleøker 1853, or Bali Sardinella fishery in Bali Strait can reach high biomass level due to upwelling process in east monsoon, starting end of April up the beginning of October. Lemuru has a common season pattern, e.i., season in September to December and low season in other months of the year, although lemuru can be caught all year round. Yearly season often changes due to the influence of El Nino. El Nino also affects the landings of lemuru in Bali Strait, where as high landings are during El Nino and low landings during anti El Nino.

\section{PENDAHULUAN}

Musim dan daerah penangkapan erat kaitannya dengan migrasi ikan. Ikan setelah memijah di daerah pemijahan, larvanya kemudian hanyut ke daerah asuhan (denatant), kemudian setelah mencapai umur atau panjang tertentu rekrut (recruitment) ke suatu daerah (daerah penangkapan) di mana mereka menjadi dewasa (Cushing, 1981; Holden \& Raitt, 1975). Atau dari daerah pemijahan larva hanyut ke daerah di mana kemudian tumbuh menjadi stok dewasa (denatant), dan kemudian kembali ke daerah pemijahan (contranatant) demikian seterusnya. Ada ikan yang daerah pemijahan dan daerah asuhan (dewasanya) pada perairan yang berbeda. Ikan-ikan salmon memijah di sungai kemudian larvanya hanyut menuju laut dan dewasa di laut di mana mereka ditangkap oleh nelayan, dan kemudian kembali lagi ke sungai untuk memijah (anadromous). Tetapi ada juga sebaliknya, sebagai contoh belut, mereka bertelur di laut dan menjadi dewasa di air tawar di mana mereka ditangkap (katadromous).

Ikan akan mencari dan memilih suatu kombinasi optimum tertentu kondisi-kondisi fisik dan biologi di suatu lingkungan perairan. Hampir semua stok ikan mempunyai temperatur yang spesifik misalnya, ikan sardin "iwashi" (S. melanosticta) mempunyai kisaran temperatur optimum $12-16^{\circ} \mathrm{C}$ dan temperatur memijah $13-17^{\circ} \mathrm{C}$ (Laevastu \& Hela, 1970). Contoh lain misalnya, penelitian jenis-jenis ikan tuna yang barangkali merupakan salah satu penelitian yang paling maju di dunia, sehingga dapat digambarkan kisaran temperatur untuk distribusi dan penangkapannya (Gambar 1).

Ikan lemuru, Sardinella lemuru Bleeker, 1853, adalah merupakan salah satu jenis ikan pelagis kecil yang secara ekonomis sangat penting artinya bagi kehidupan masyarakat di sekitarnya. Penyebarannya terutama terkonsentrasi di perairan Selat Bali dan sekitarnya. Yang sudah jelas diketahui adalah penyebarannya ke barat sampai Prigi dan ke timur sampai Selat Alas. Menurut Whitehead (1985), penyebaran ikan lemuru adalah meliputi Samudra Hindia bagian timur (Phuket, Thailand, pantai-pantai selatan Jawa Timur dan Bali; Australia Barat) dan Samudra Pasifik bagian barat (Laut Jawa ke utara sampai Filipina, Hong Kong, Pulau Taiwan sampai Jepang bagian selatan.

Di antara jenis-jenis ikan pelagis kecil, ikan lemuru banyak menarik perhatian banyak mahasiswa maupun sarjana baik dari dalam maupun luar negeri untuk melakukan penelitian. Beberapa doktor, master maupun sarjana telah dihasilkan dari penelitian ikan lemuru, baik menyangkut sumber daya, maupun sosial ekonomi.

Ikan lemuru termasuk ikan pelagis kecil yang bergerombol, yang dapat membentuk suatu biomassa yang tinggi di perairan-perairan di mana terjadi proses penaikan air (upwelling) seperti di perairan Selat Bali. $\mathrm{Hal}$ ini sesuai dengan perilaku spesies pelagis kecil bergerombol adalah pemakan plankton atau

\footnotetext{
*) Peneliti pada Balai Riset Perikanan Laut, Jakarta

*) Peneliti pada Pusat Riset Perikanan Tangkap, Jakarta
} 
Bonito

Tuna Sirip Biru Selatan

Albakora

Tuna Mata Besar

Cakalang

Tongkol

Madidihang
Temperatur ${ }^{\circ} \mathrm{C}$
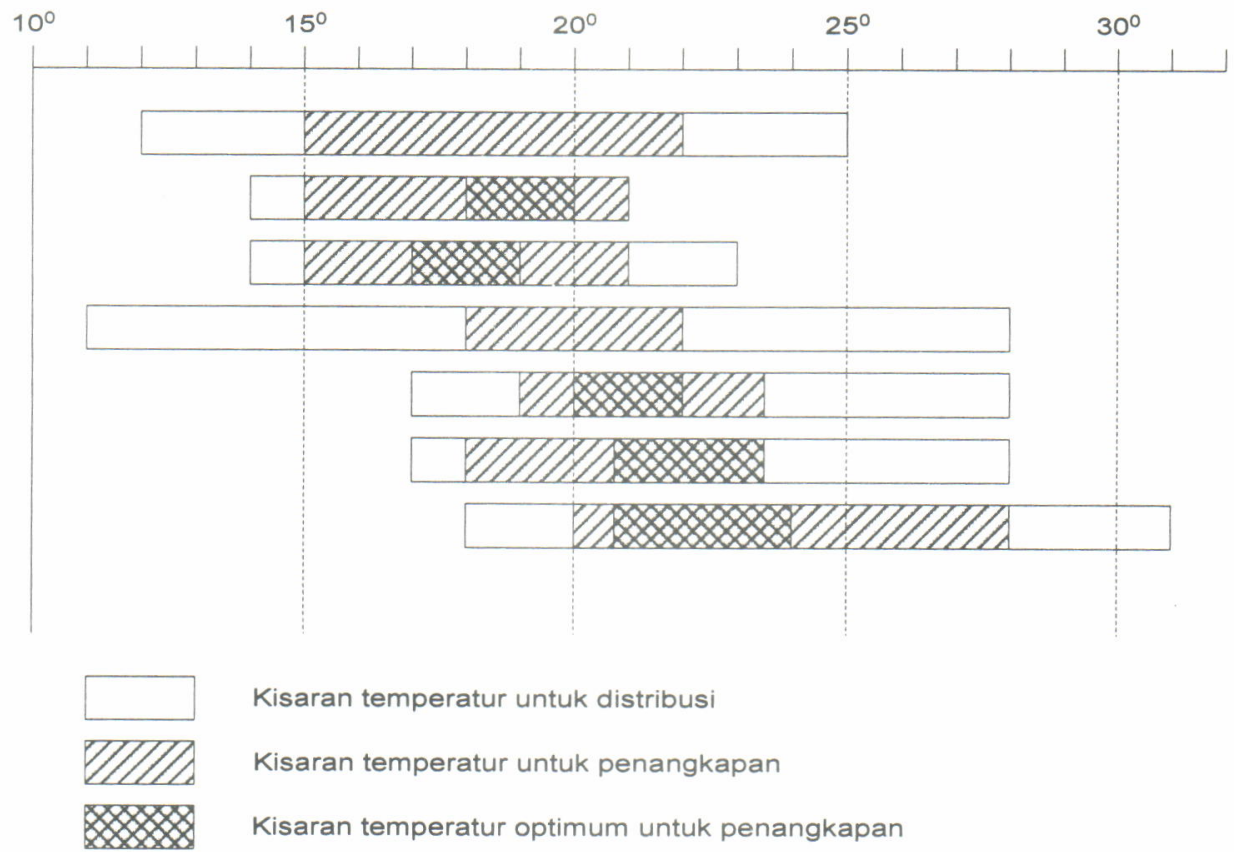

Gambar 1. Kisaran temperatur untuk distribusi dan penangkapan jenis-jenis tuna (setelah Uda). (Sumber: Laevastu dan Hela, 1970)

Figure 1. Range of temperature in tuna distribution and fishing (Source Laevastu \& Hela, 1970).

particulate plankton, dan tingkat tropik yang relatif rendah dan posisi awalnya dalam rantai baharinya (Csirke, 1988). Hubungannya dalam rantai makanan biasanya sederhana, misalnya fitoplanton-anchovi, atau fitoplankton-zooplankton-sardin. Upwelling di Selat Bali terjadi pada musim timur (Burhanuddin \& Praseno, 1982), di mulai akhir bulan April dan berakhir permulaan bulan Oktober (Salijo, 1973). Produksinya sangat fluktuatif, terjadi puncak yang tinggi dan lembah yang dalam setiap beberapa tahun.

Ikan lemuru diduga memijah pada bulan Juni-Juli di sekitar perairan Selat Bali (Dwiponggo, 1972), yang dibenarkan oleh Ritterbush (1975) dan Burhanuddin et. al.,. (1984). Merta (1992), dengan menganalisis TKG ikan lemuru di Selat Bali menduga puncak musim pemijahannya adalah pada bulan Juli, yang bersamaan dengan terjadinya puncak upwelling di Selat Bali. Ikan-ikan sempenit mulai tertangkap pada bulan-bulan Agustus-September (Wudianto, 2001) dan yang terbesar ( $F L>20 \mathrm{~cm}$ ) tertangkap pada bulan Mei di Selat Bali.

Ikan tuna sirip biru selatan (SBT), memijah di perairan tropis selatan Jawa dan Nusa Tenggara pada bulan-bulan September sampai Maret (Kailola et. al., 1993). Ikan-ikan yuwana bermigrasi ke arah selatan, dan ikan-ikan yang berumur 1-3 tahun terdapat di perairan barat-daya Australia. Makin ke timur ikan sirip biru selatan makin bertambah besar, sampai di perairan Selandia Baru. Kemudian setelah dewasa, mereka kembali ke Samudra Hindia (selatan Jawa dan Nusa Tenggara) untuk memijah. Bagi nelayan-nelayan tuna longline yang beroperasi di Samudra Hindia, bulan-bulan September adalah bulan-bulan di mana ikan tuna sirip biru selatan tertangkap sebagai "by-product" longline tuna.

\section{BAHAN DAN METODE}

\section{Data yang Digunakan}

Di perairan Selat Bali ada dua tempat pendaratan ikan yang besar, yaitu Muncar, Kabupaten Banyuwangi di Jawa Timur dan Pengambengan di Kabupaten Jembrana, Bali. Data yang digunakan untuk menganalisis musim penangkapan ikan lemuru di perairan Selat Bali adalah produksi lemuru bulanan yang diperoleh dari TPI Mina Blambangan Muncar selama 10 tahun (1993-2002) (Tabel Lampiran 1). Dengan asumsi bahwa trend produksi lemuru bulanan baik di Muncar maupun di Pengambengan adalah sama, karena nelayan-nelayan dari kedua lokasi menangkap di daerah penangkapan yang sama.

\section{Metode Analisis}

Untuk menganalisis musim penangkapan ikan lemuru digunakan metode persentase rata-rata (the average percentage methods), yaitu suatu analisis runtun waktu (time series analysis), yang dikemukakan oleh Spiegel (1961) dan Purwasasmita (1993). Data dalam Tabel 2 kemudian diolah menggunakan cara-cara/rumus berikut: 
Pertama-tama dihitung produksi rata-rata bulanan untuk masing-masing tahun dalam Tabel 2 dengan rumus berikut:

$$
\bar{Y}=\frac{1}{m} x \sum_{i=1}^{m} Y i
$$

di mana:

$$
\begin{aligned}
& Y=\begin{array}{l}
\text { rata-rata bulanan dalam tahun yang } \\
\text { bersangkutan }
\end{array} \\
& \text { produksi bulanan dalam tahun yang } \\
& \text { persangkutan }
\end{aligned}
$$

Kemudian produksi setiap bulannya dalam Tabel 2 dibagi dengan rata-rata bulanan dari tahun yang bersangkutan:

$$
Y_{p}=\frac{Y}{\bar{Y}} x 100 \% \text {....... }
$$

di mana:

$Y p=$ adalah hasil bagi produksi bulanan dengan produksi rata-rata bulanan dalam tahun yang bersangkutan

Kalau nilai-nilai Yp tidak ada yang ekstrim, maka dihitung nilai tengah setiap bulannya berdasarkan jumlah tahun yang ada:

$$
\text { Mean }=\frac{1}{t} x \sum_{y=1}^{t} U p
$$

di mana:

$$
\mathrm{t}=\text { jumlah tahun data yang dianalisis }
$$

Kalau semua nilai Mean bulanan tersebut dijumlahkan nilainya sama dengan $1,200 \%$, maka nilai-nilai Mean tersebut sama dengan Indeks Musim yang dimaksud. Tetapi kalau jumlah nilai-nilai Mean tersebut tidak sama dengan 1,200\%, maka dilakukan penyesuaian, yaitu:

1. Kalau jumlah nilai-nilai Mean sama dengan $X$, di mana nilai $X>1.200$, maka dilakukan penyesuaian dengan mengalikan setiap nilai Mean dengan $1.200 / X$. Nilai-nilai Mean yang sudah disesuaikan jumlahnya akan menjadi 1.200, akan sama dengan Indeks Musim yang dimaksud.

2. Kalau nilai $X<1.200$, maka masing-masing nilai Mean dikalikan dengan 1.200/X. Nilai-nilai Mean yang baru jumlahnya akan menjadi 1.200 , adalah Indeks Musim yang dimaksud.

Kalau data Up ada yang ekstrim, maka tidak bisa menggunakan nilai-nilai Mean, tetapi Median. Kalau jumlah niai-nilai Median yang diperoleh sama dengan 1.200, maka nilai-nilai Median tersebut adalah sama dengan nilai-nilai Indeks Musim. Tetapi kalau jumlahnya tidak sama dengan 1.200, maka dilakukan penyesuaian mengikuti aturan pada butir-butir 1 dan 2 di atas. Kalau ada data Yp yang ekstrim, maka dapat juga digunakan Meannya, dengan menghilangkan data yang ekstrim terlebih dahulu (Spiegel, 1961).

\section{HASIL DAN BAHASAN}

\section{Musim Ikan Lemuru di Selat Bali}

Data produksi bulanan yang didaratkan di TPI Mino Blambangan, Muncar, disajikan dalam Tabel Lampiran 1. Kemudian masing-masing data bulanan dalam Tabel Lampiran 1 dibagi dengan rata-rata bulanan dari tahun yang bersangkutan lalu dikalikan dengan 100\%. Misalnya data bulan Januari 1993 dibagi dengan rata-rata bulanan tahun 1993 dikalikan dengan $100 \%$ adalah $934,64 / 2046,51 \times 100 \%=45,67 \%$, dan hasil-hasilnya disajikan dalam Tabel Lampiran 2. Kemudian produksi bulanan dalam Tabel Lampiran 2 dihitung total masing-masing bulannya. Karena data dalam Tabel Lampiran 2 ada yang ekstrim, maka untuk rata-rata bulanannya digunakan Median. Jumlah nilai-nilai Mediannya (Januari sampai dengan Desember) adalah 1032,32. Nilai tersebut di bawah 1.200 sehingga perlu disesuaikan (adjusted). Masingmasing nilai Median dikalikan dengan $1.200 / 1032,32=1,162430254$. Nilai-nilai Median yang sudah disesuaikan (adjusted median) sekarang jumlahnya sama dengan 1200,00. Nilai-nilai Median yang sudah disesuaikan adalah Indeks Musim yang dicari.

Jika nilai Indeks Musim lebih besar dari 100\% atau di atas rata-rata (Waldron, 1963 dalam Purwasasmita, 1993) adalah musim ikan dan kalau nilainya lebih kecil dari $100 \%$ berarti tidak musim ikan. Tetapi kalau nilai $\mathrm{IM}=100 \%$, maka sesuai dengan harga rata-rata bulanan, sehingga dapat dikatakan bahwa keadaan normal atau berimbang (Gambar 2). Gambar tersebut memperlihatkan pola umum musim ikan lemuru di Selat Bali, di mana musim lemuru terjadi pada bulanbulan September sampai dengan Desember, sedangkan tidak musim pada bulan-bulan Januari sampai dengan Agustus.

Dilihat musim-musim pada setiap tahunnya, polanya tidak selalu sama. Pada tahun 1993, 1994, 1997, 2001, dan 2002 trend produksi mengikuti pola musim umum, tetapi trend produksi pada tahun-tahun 1995, 1996, 1998, 1999, dan 2000 tidak mengikuti pola musim umum (Gambar Lampiran 1). Yang luar biasa adalah produksi bulanan tahun 1995. Dalam tahun ini, produksi bulanan pada bulan Januari tinggi, kemudian menurun sampai bulan April, padahal pola umumnya bulan April adalah tidak musim. Produksi tertinggi adalah pada bulan Oktober lalu menurun tajam sampai Desember, lain dari pola umumnya. Produksi bulanan pada tahun 1998 juga tidak mengikuti pola musim yang umum. Produksi tinggi justru pada musim timur, yaitu pada bulan-bulan Maret sampai dengan Juli, dengan puncak-puncaknya pada bulan-bulan Maret dan Juni (Gambar Lampiran 1). 


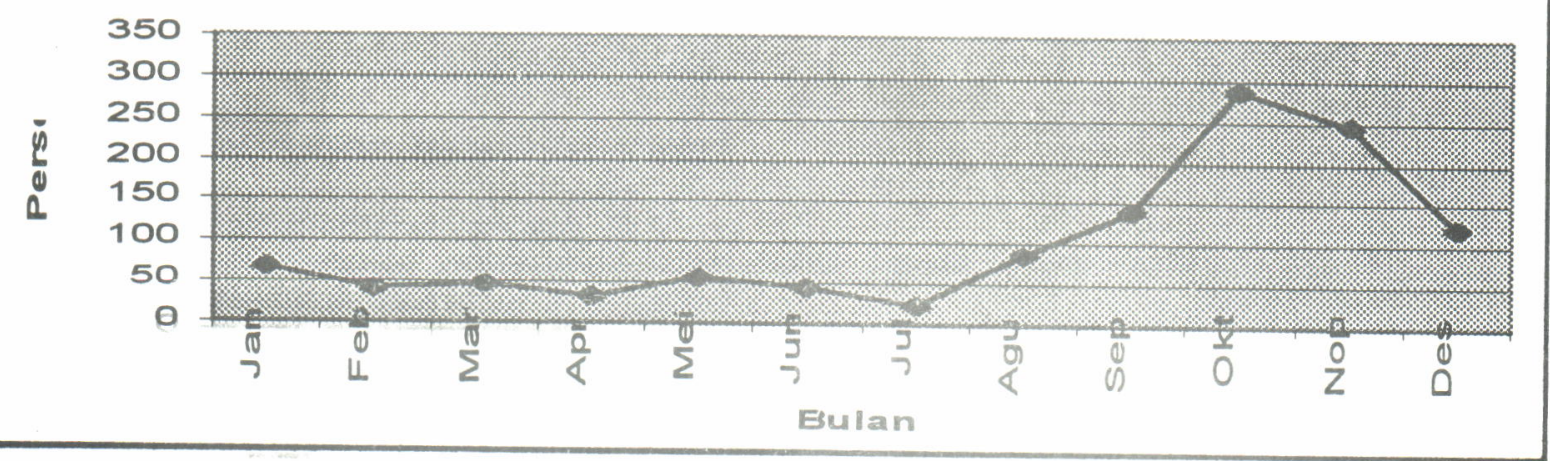

Gambar 2. Indeks Musim ikan lemuru di perairan Selat Bali.

Figure 2. Season index of lemuru in Bali Strait waters.

Pada umumnya ikan beruaya, termasuk juga ikan lemuru, dipengaruhi oleh dua faktor utama, yaitu faktor luar atau lingkungan yang secara langsung atau tidak langsung mempengaruhi aktivitas ruaya ikan. Faktor dalam yang terdapat di dalam tubuh ikan, misalnya sekresi kelenjar hormon dan lain-lainnya yang berhubungan dengan faktor luar di atas (Effendie, 1997). Oleh karena itu, adanya fluktuasi musim mungkin ada kaitannya dengan kedua faktor yang disebutkan di atas.

Menurut Wudianto (2001) dalam menentukan musim lemuru digunakan data CPUE, karena akan lebih akurat dibandingkan dengan menggunakan data produksi. Rata-rata CPUE bulanan pukat cincin di Muncar berdasarkan data tahun 1996-1998, menunjukkan bahwa hasil tangkapan lemuru tinggi antara bulan Agustus sampai Februari dan mencapai puncaknya pada bulan Oktober dengan CPUE sebesar 2.627 kg/hari-kapal, sedangkan CPUE rendah di bawah $500 \mathrm{~kg}$ per hari-kapal adalah pada bulan Maret sampai Juli. Perkembangan CPUE rata- rata bulanan di atas mirip dengan perkembangan produksi bulanan rata-rata tahun 1995 (Gambar Lampiran 1). Purwasasmita (1993) juga menggunakan data CPUE untuk menentukan Indeks Musim Ikan Cakalang di perairan sekitar Sorong.

Menurut Dwiponggo (1982), pada waktu musim lemuru, penyebarannya ke arah barat sampai Teluk Grajagan, sedang di daerah Pulau Bali dari Candikesuma ke tenggara sampai semenanjung bukit. Datangnya musim lemuru di Selat Bali umumnya bersamaan dengan musim hujan (Soerjodinoto, 1960). Musim hujan di perairan Selat Bali terjadi pada musim barat laut (Northwest Monsoon), yaitu pada bulan Desember sampai Februari atau Maret (Dwiponggo, 1982).

Produksi total lemuru di Selat Bali (Gambar 3), sangat berfluktuasi. Sejak perkembangan alat tangkap pukat cincin di Selat Bali, terjadi tiga puncak produksi, yaitu tahun 1983, 1991, dan 1998 masingmasing 48.076 ton, 61.669 ton, dan 77.572 ton,

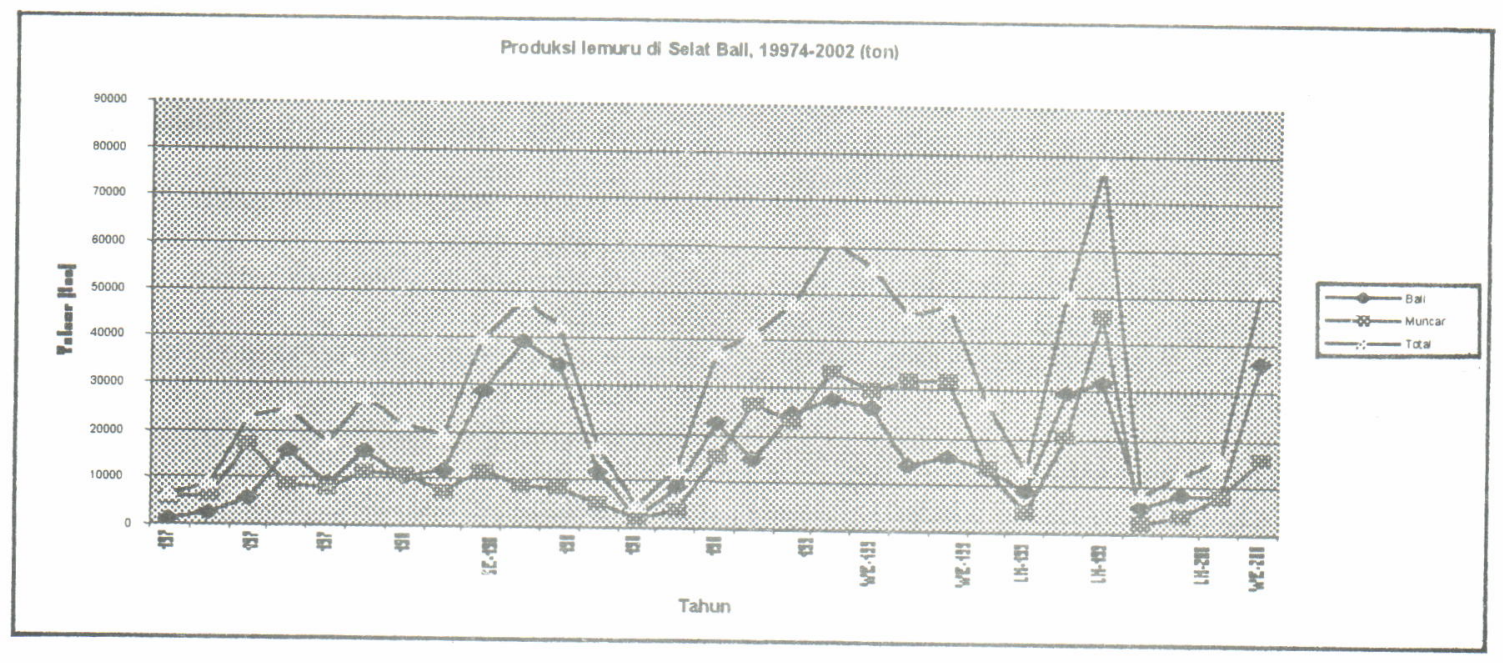

Gambar 3. Perkembangan produksi total ikan lemuru di Selat Bali.

Figure 3.

Total production progress of lemuru in Bali Strait. 
sedangkan produksi yang terendah terjadi pada tahun 1986, 1996, dan 1999 masing-masing 4.661 ton, 13.327 ton, dan 8.286 ton. Kalau perubahan pola musim dihubungkan dengan fluktuasi produksi total, maka pada tahun 1995 dan 1996 produksi menurun drastis sejak tahun 1991 dan mencapai terendah tahun 1996. Perubahan pola musim juga terjadi pada tahun 1998, 1999, dan 2000 di mana produksi mencapai puncak pada tahun 1998 setelah mencapai produksi terendah pada tahun 1996, kemudian turun dengan drastis dan mencapai terendah pada tahun 1999. Walaupun produksi pada tahun 2000 naik menjadi 12.156 ton, mungkin dampak dari penurunan drastis sebelumnya masih sangat berpengaruh terhadap produksi tahun 2000. Jadi pola umum musim lemuru di Selat Bali akan berubah kalau terjadi fluktuasi-fluktuasi yang sangat tajam dalam produksi, terutama karena pengaruh lingkungan.

Southern Oscillation Index (SOI) berdampak sangat nyata pada pendaratan ikan lemuru, dengan tahun-tahun terjadinya El Nino menghasilkan pendaratan-pendaratan yang sangat tinggi, dan tahun-tahun Anti EI Nino menghasilkan pendaratanpendaratan yang sangat rendah (Mathews et. al., 2001). Tingginya pendaratan-pendaratan ikan lemuru yang terjadi pada tahun-tahun terjadinya EI Nino, barangkali karena upwelling yang kuat menyebabkan terjadinya produktivitas primer dan sekunder yang tinggi yang diperlukan bagi rekruitmen dan kelangsungan hidup yang tinggi dari ikan lemuru.

Musim perlu diketahui untuk memudahkan menangkap suatu sumber daya ikan dalam jumlah yang cukup banyak. Tetapi penangkapan yang berlebihan akan menyebabkan sumber daya ikan yang bersangkutan dapat mengalami kelebihan tangkap (overfishing). Oleh karena itu, salah satu teknik jengelolaan perikanan adalah untuk menutup musim-musim atau daerah-daerah penangkapan tertentu, kalau musim penangkapannya dapat diketahui secara pasti, sehingga dapat diketahui dengan benar kapan mulai penangkapan ditutup dan kapan dibuka lagi.

\section{Manfaat Musim Ikan, Khususnya Lemuru}

Pada musim ikan di suatu daerah, di mana ikan tersedia secara melimpah dan keadaan cuaca memungkinkan, dapat dilakukan penangkapan secara efektif, sehingga waktu untuk mencari gerombolangerombolan ikan menjadi relatif lebih kecil. Tetapi di suatu daerah yang belum dikelola dengan baik, akan terjadi penangkapan secara besar-besaran dan nelayan-nelayan akan berlomba-lomba untuk memperoleh hasil yang sebanyak-banyaknya. Kalau keadaan ini terus tidak terkendali, maka akan menyebabkan terjadinya penangkapan yang berlebihan (overfishing), mula-mula terjadi lebih tangkap pertumbuhan (growith overfishing), dan kalau keadaan ini terus berlangsung akan disusul oleh lebih tangkap rekruitmen (recruitment overfishing) terhadap sumber daya ikan yang bersangkutan. Kalau hal terakhir ini sudah terjadi, kelihatannya tinggal selangkah lagi sumber daya yang bersangkutan akan runtuh (collaps).

\section{Teknik Pengololaan dengan Penutupan Musim dan Area}

Penutupan musim (closed season) adalah melarang kegiatan penangkapan (dalam suatu area atau suatu perikanan secara keseluruhan) untuk suatu periocle wakiu tertentu, biasanya untuk melindungi yuwana dan ikan-ikan pemijah (SEAFDEC, 2003). Penutupan musim merupakan suatu pengendali yang baik bagi jumlah penangkapan, asalkan metode-metode teknis dan ilmiah yang tercakup dalam menentukan lamanya musim dapat dipecahkan. Misalnya, tanggal penucupan mungkin ditentukan oleh tanggal di mana suatu tingkat hasil tangkapan yang telah ditentukan sebelumnya tercapai (Gulland, 1971). Tetapi, kalau tidak ada kontrol tambahan terhadap besarnya armada, maka operator-operator individu akan menambah armadanya untuk memperbesar porsinya pada hasil tangkapan total. Hasil dari kenaikan armada total akan berarti suatu pemendekan musim, barangkali sampai hanya beberapa hari saja. Ini telah terjadi pada perikanan yang diatur dengan cara ini, misalnya tuna di wilayah Inter-American Tropical Tuna Commission (I-ATTC). Perikanan lemuru di Selat Bali tidak dikelola derigan cara ini, tetapi dengan menentukan jumlah armada pukat cincin yang boleh beroparasi, ukuran jarring, dan ukuran mata jaring.

Pelarangan penangkapan pada musim-musim dan tempat-tempat tertentu, merupakan teknik-teknik tertua di dalam literatur pengeiolaan perikanan. Menurut Gulland (1974), cara-cara ini akan efektif apabila hasil-hasil tangkapan pada waktu-waktu dan tempat-tempat tertentu terutama terdiri dari ikan-ikan yang ukurannya lebih kecil dari ukuran optimum pada waktu pertama kali tertangkap (optimum size at first capture)

Yuwana ikan tuna biasanya tertangkap bercampur dengan tuna kecil ata! cakalang berukuran kecil, menggunakan alat tangkap permukaan terutama pukat cincin. Jika suatu perairan telah diketahui menjadi tempat pemijahan (yang dapat diestimasi melalui persentase kematangan gonad ikan yang tertangkap) maka pada bulan-bulan tertentu harus dilakukan upaya penutupan daerah dari kegiatan penangkapan (closed seasons/periods).

Pelarangan penangkapan pada daerah-daerah rumpon pada waktu-waktu tertentu, di mana banyak muncul yuwana ikan tuna mata besar, telah diterapkan di Samudra Atlantik. Dengan cara penutupan ini dapat menurunkan mortalitas penangkapan bagi yuwana ikan mata besar, yaitu $45 \%$ untuk ikan yang baru rekrut, $30 \%$ bagi ikan yang berumur satu tahun, dan $10 \%$ bagi ikan yang berumur dua tahun (IOTC SECRETARY, 2000) 
Di Samudra Hindia barat laut telah diimplementasikan penutupan daerah rumpon pada tahun 1998, yang meliputi daerah $0^{\circ}-10^{\circ} \mathrm{U}, 45^{\circ}-70^{\circ} \mathrm{T}$ pada bulan Agustus sampai dengan Nopember. Percobaan ini belum memberikan pengaruh terhadap penangkapan yuwana ikan tuna mata besar, karena waktu penutupannya tidak tepat (Romanove, 2000).

Puncak pemijahan ikan lemuru diduga pada bulan Juni-Juli, tetapi daerah pemijahannya belum diketahui dengan pasti. Yang jelas, pada bulan-bulan tertentu sempenit (ikan-ikan lemuru $<11 \mathrm{~cm}$ ) banyak tertangkap di Teluk Pangpang, oleh bagan tancap. Pengelolaan dengan menerapkan teknik penutupan musim dan area kiranya memungkinkan dilakukan di Teluk Pangpang. Sebelum teknik ini dapat diterapkan, pertama haruslah diketahui kapan sempenit muncul, untuk memulai penutupan musim penangkapan. Kedua, berapa lama penutupan ini berlangsung. Sadhotomo (1995), melalui simulasi, menunjukkan bahwa apabila sempenit yang tertangkap lebih dari $8 \%$ produksi total ikan lemuru, akan mempengaruhi produktivitas pukat cincin selanjutnya. Berarti bahwa untuk menjaga produktivitas pukat cincin, sempenit hanya boleh tertangkap $8 \%$ dari produksi total ikan lemuru. Bila tidak ditangkap, maka sempenit akan mati sia-sia karena mortalitas alami ikan lemuru sangat tinggi, mencapai 1,0 (Merta, 1992), bahkan dapat mencapai 2,17 per tahun (Budihardjo ot. al., 1990).

\section{KESIMPULAN DAN SARAN}

\section{Kesimpulan}

1. Ikan lemuru di perairan Selat Bali dan sekitarnya mempunyai pola musim yang umum, yaitu bulanbulan September sampai dengan Desember adalah musim, dan bulan-bulan lainnya tidak musim, walaupun lemuru juga tertangkap sepanjang tahun. Pola umum ini bisa berubah secara tahunan tergantung pada terjadinya proses El Nino.

2. Dengan demikian tidak dapat diketahui musim lemuru pada suatu tahun tertentu secara pasti, karena tergantung pada ada atau tidak adanya serta kuat lemahnya atau proses EI Nino pada tahun tersebut.

\section{Saran}

Untuk menganalisis musim suatu perikanan menggunakan data statistik perikanan, diperlukan data runtun waktu yang cukup panjang, kira-kira 10 tahun untuk mengeliminasi sedikit mungkin pengaruh terjadinya fluktuasi tahunan. Kemudian data tahunannya dilihat apakah terjadi perubahanperubahan pola musim yang mencolok (tidak mengikuti pola musim yang umum).

\section{DAFTAR PUSTAKA}

Budihardjo, S., E. M. Amin \& Rusmadji. 1990. Estimasi pertumbuhan dan tingkat kematian Ikan Lemuru di Selat Bali. Jurnal Penelitian Perikanan Laut. 55:79-90.

Burhanuddin \& D. P. Praseno. 1982. Lingkungan perairan Selat Bali. Prosiding Seminar Perikanan Lemuru. Banyuwangi, 18-21 Januari 1982. Hal. 2732.

Burhanuddin, M. Hutomo, S. Martosewoyo, \& R. Moeljanto. 1984. Sumber daya ikan lemuru. LONLIPI, Jakarta. 70 hal.

Csirke, J. 1988. Small shoaling fish stoks. In J. A. Gulland, ed. Fish population dynamics. $2^{\text {nd }}$ Ed. John Wiley \& Sons, Chichester. P. 271-302.

Cushing, D. H. 1981. Fisheries biology. A study in population dynamics. $2^{\text {nd }}$ Ed. The Univ. of Wisconsin Press., Wisconson. 295 p.

Dwiponggo, A. 1972. Perikanan dan penelitian pendahuluan kecepatan pertumbuhan lemuru $(S$. longiceps) di Muncar, Selat Bali. LPPL 1/72-PL. 021/72: $117-144$.

Dwiponggo, A. 1982. Beberapa aspek ikan lemuru, Sardinella spp. Prosiding Seminar Perikanan Lemuru. Banyuwangi, 18-21 Januari 1982. Buku 2. Makalah-makalah yang disajikan. Hal. 75-89.

Effendie, H. M. I. 1997. Biologi perikanan. Yayasan Pustaka Nusantara. Yogyakarta. 163 hal.

Gulland, J. A. 1971. Management. IOFC/DEV/71/4. FAO, Rome. 8 p.

1974. Guidelines for fishery management. IOFC/DEV/74/36. FAO, Rome. 84 p.

Holden, M. J. \& D. F.S. Raitt (Eds.). 1975. Manual of fisheries science. Part 2. Methods of resource investigation and their application. FAO. Fish. Tech. Pap., (115)Rev. 1:214.

IOTC SECRETARY. 2000. Time and area closure of the fishery on floating objects. IOTC, Seychelles. 8 p.

Kailola, P. J., M. J. Williams, P. C. Stewart, R. E. Reichelt, A. McNee, \& C. Grieve. 1993. Australian fisheries resources. Bur. Resour. Sci., Depart. Prim. Indust. and Energy, and the Fish. Res. and Develop. Corp. Canberra, Australia. 422 p.

Laevastu, T. \& I. Hela. 1970. Fisheries oceanography. Fishing News (Books) Ltd., London. 238 hal.

Mathews, C. P., A. Ghofar, G. S. Merta, N. Hendiarti, \& H. Lestiana. 2001. Effects of frontal systems, 
upwelling, and EI Nino on the small pelagic fisheries of the lesser Sunda Islands, Indonesia. In Pros. The First International Symposium on Geographic Information Systems (GIS) in Fishery Science (Seattle, Washington, U.S.A.: 2-4 March 1999), Ed. By T. Nishida, P. J. Kailola \& C. E. Hollingworth. Fish. GIS Res. Group, Saitama, Japan. Pp. 65-88.

Merta, I. G. S. 1992. Dinamika populasi ikan lemuru, sardinella lemuru Bleeker 1853 (Pisces:Clupeidae) di perairan Selat Bali dan alternatif pengelolaannya. Desertasi. Fakultas Pascasarjana, IPB, Bogor. 201 hal. Tidak dipublikasikan.

Purwasasmita, R. 1993. Musim penangkapan ikan cakalang, Katsuwonus pelamis, dengan kapalkapal huhate dan pengaruhnya terhadap peningkatan produksi di perairan sekitar Sorong. Jurnal Penelitian Perikanan Laut, (79): 1-13.

Ritterbush, S. W. 1975. The assessment of the population biology of the Bali strait lemuru fishery. LPPL 1/75-PL. 051/75. 37 p.

Romanov, E. V. 2000. By catch in the sovyet purse seine tuna fisheries on FAD-associated schools in north equatorial area of the Western Indian Ocean. IOTCMPTT/00/10. $7 \mathrm{p}$.

Salijo, B. 1973. Keadaan oseanografi daerah-daerah penangkapan ikan lemuru di Selat Bali. LPPL 2/73-PL. 042/73. Hal. 1-16.
SEAFDEC. 2003. Responsible fisheries management. Regional guidelines for responsible fisheries in Southeast Asia. SEAFDEC. MFRDMD/SP/3: 69 p.

Spiegel, M. R. 1961. Theory and problems of statistics. Schaum's Outline Series, McGraw Hill Book co., New York. 359 p.

Soerjodinoto, R. 1960. Synopsis biological data on lemuru, clupea (Harengula) longiceps (C.V.). FAO Fisheries Biology Synopsis, (15): 313-328.

Whitehead, P. J. P. 1985. FAO species catalogue. Vol. 7. Clupeoid Fishes of the World. An Annotated and Illustrated Catalogue of tge Herrings, Sardines, Pilchards, Sprats, Anchovies and Wolfherrings. Part 1-Chirocentridae, Clupeidae and Pristigasteridae. FAO Fish. Synop., (125) Vol. 7,Pt. 1: 303 p.

Sadhotomo, B. 1995. Dampak penangkapan ikan muda terhadap produktivitas perikanan (simulasi dasar perikanan lemuru, Sardinella longiceps) di Selat Bali. Jurnal Penelitian Perikanan Laut (60): 51-66.

Wudianto. 2001. Analisis sebaran dan kelimpahan ikan lemuru (Sardinella lemuru Bleeker, 1853) di perairan Selat Bali: kaitannya dengan optimasi penangkapan. Desertasi. Program Pasca Sarjana, IPB, Bogor. 221 hal. Tidak dipublikasikan. 
Gambar lampiran 1. Fluktuasi hasil tangkapan bulanan ikan lemuru, Sardinella lemuru, Bleeker 1853 yang didaratkan di Muncar, 1993-2002

Figure annext 1. Montly fluetuation of Sardinella lemuru catch landed at Muncar, 1993-2002
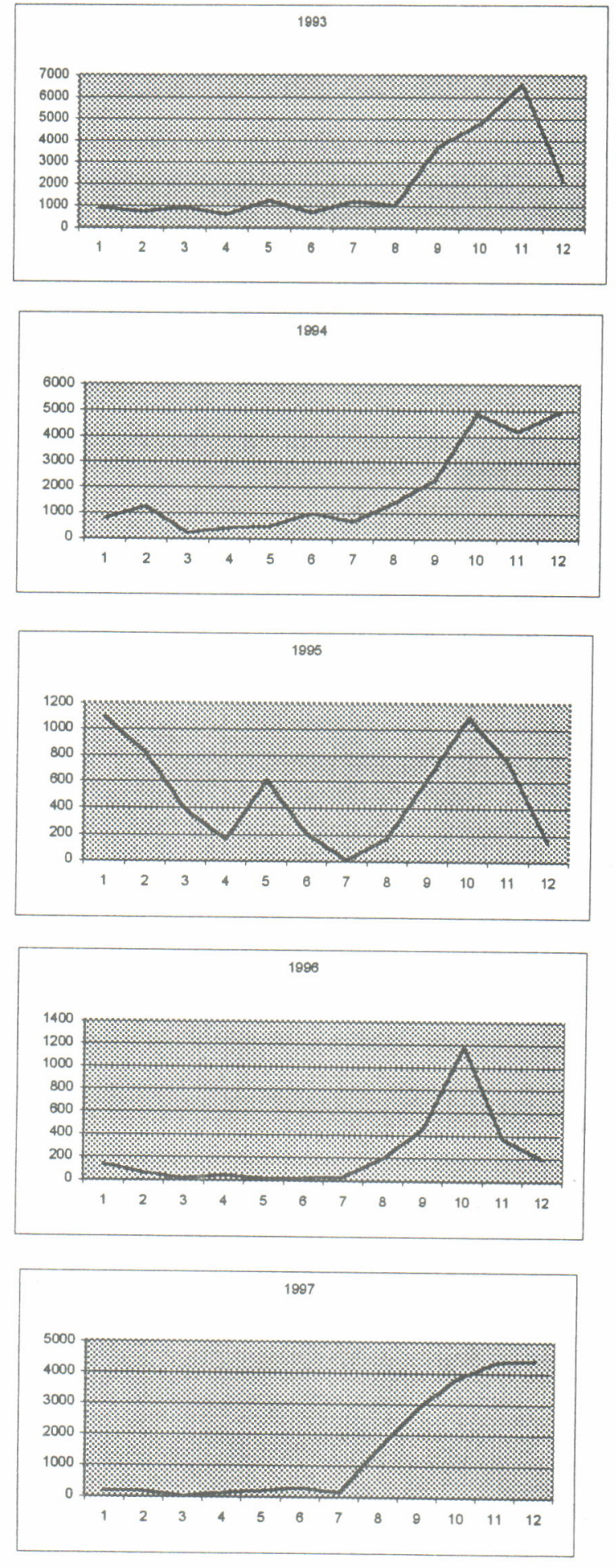

C:ILemurulIM_Lemuru
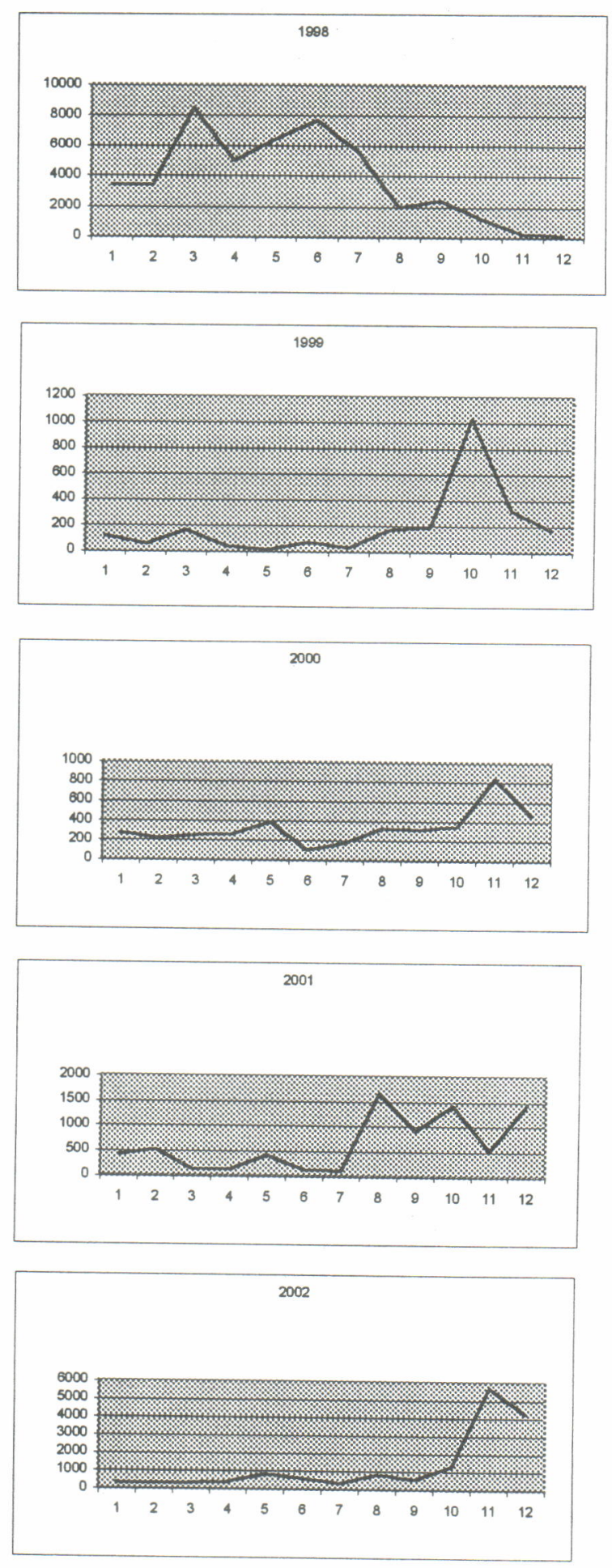


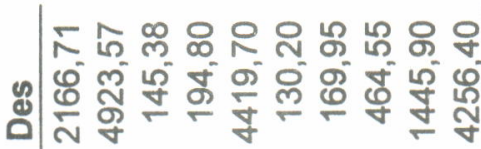

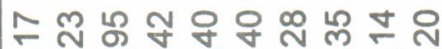

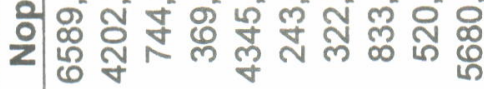

유슝ㅇㅇㅇㅇㅇㅇㅇㅛ

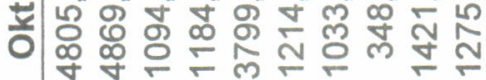

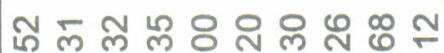
ڤి:

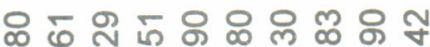

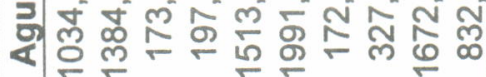

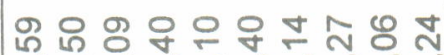
इ

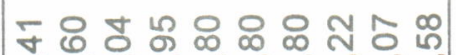
รัป๋

๑ ป。

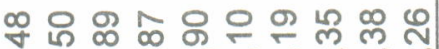

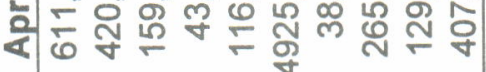

ட

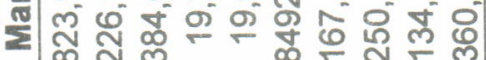
용 \% 용 8 워 ซ น. ํㅝㄴ

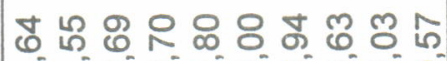
กั 뜬 है을 बळ $\frac{0}{\frac{0}{2}}$

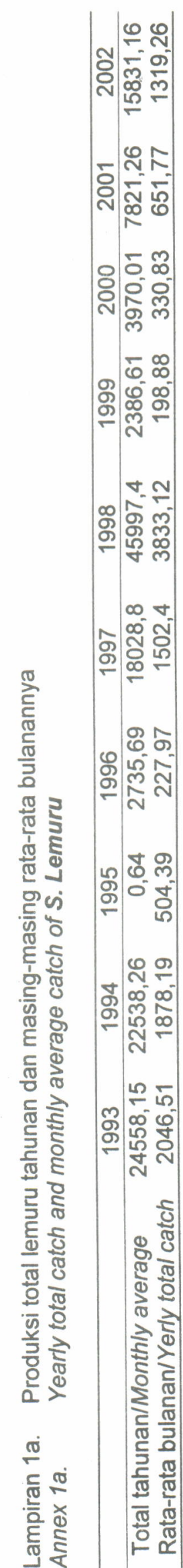




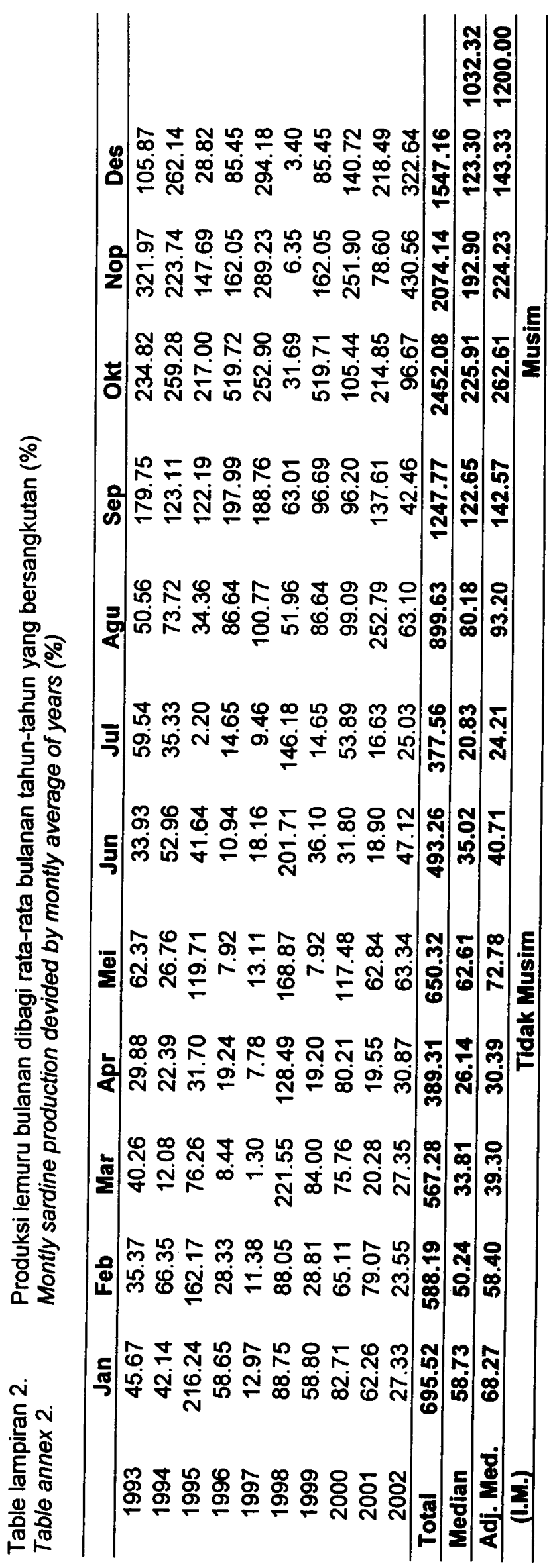

